\title{
ACCULTURATION OF THE ISLAMIC URBAN ARTIFACTS IN JAVA
}

\author{
K P Tucunan*, D Rahmawati
}

\author{
Institut Teknologi Sepuluh Nopember Indonesia
}

\begin{abstract}
Acculturation process in Indonesia significantly happened in Java, an island that has been the center of cultural development until today. Islamic heritage has played a major role in the Javanese acculturation process whereas the acculturation itself is a social process where a social group meets another group embedded with their culture. In this study, it was found that existing Islamic artifacts were the result of acculturation from the multiple interactions between Javanese (local) culture, Hinduism, Chinese and Arabic culture. The types of sites and features include: mosques and tombs complex and the types of artifacts include: coins/ currencies and ceramics/ stones and Islamic calligraphy engravings. Forms of acculturation that occur include 1). Coping and adaptation in the spatial configuration of Islamic heritage sites. 2). modification in architectural design and ornaments artifacts, and last 3). Acculturation in artifacts of the art and writing artifacts.
\end{abstract}

Keywords: Islamic Heritage, Javanese, Acculturation, Unique Mosque

\section{Introduction}

The legacy of Islamic culture is a unique inheritance because there is a process of acculturation and changes in civilization in a fairly fast time (50 years) from the Hindu-Buddhist kingdom to the Islamic kingdom (Achmad, 2017). Islam is the majority religion in Indonesia, but none of the historic Islamic sites in Indonesia has become a common concern in the international world. The registered heritage site on the list of UNESCO for cultural heritage in Indonesia are: Borobudur Temple Compounds, Komodo National Park, Prambanan Temple Compounds, Ujung Kulon National Park, Sangiran Early Man Site, Lorentz National Park, Tropical Rainforest Heritage of Sumatra, Cultural Landscape of Bali Province: the Subak System as a Manifestation of the Tri Hita Karana Philosophy (UNESCO,2017). The unique process of the acculturation causing the indigenous Islamic urban artifacts in Java, that potential to be one of the heritage sites of the UNESCO through the historic urban landscape (HUL) process with the outstanding value offers.

Acculturation process that happened during the Islamic period (1400-1600 BC) was initiated by nine agents of social changes, which Indonesian people know as "Wali Songo" or in the English call "The nine saints" they are: Sunan Maulana Malik Ibrahim, Sunan Ampel, Sunan Giri, Sunan Bonang, Sunan Drajat, Sunan Kudus, Sunan Kalijaga, Sunan Muria and Sunan Gunung Jati (Azra, 2006). There are couple deductions on how Islamic da'wah (spreading of Islamic thoughts) happening in Indonesia, first the Arabic theory (700 BC), second the Chinese theory, third the India - Gujarati theory and last is the Iran theory, but most of the people beliefs on the Arabic, Chinese and Indian- Gujarati theories compare to the Iran theory. The acculturation is also acknowledged in much previous research as quoted from Kennedy (1943) as follow "In the Indies, therefore, we find three superimposed levels of acculturation, but different parts of the islands show quite varied patterns of cultural stratification. The Hindu influence spread in appreciable force only over Sumatra, Java, Bali, and certain coastal areas of Borneo and Celebes. Its effects can still be seen in miscellaneous aspects of the culture of these districts: religious concepts, artistic forms, linguistic elements, writing, and some subtle features of social organization" 
However, this process of the acculturation causing many adaptations in the religion of Islam which are unsupported by many people who is concerned about the purity of the religion. Most of the rejecter of the concept of acculturation belies that the nine saints creating something new (bid'ah) in the Islamic religion. The bid' $^{\prime} a h^{1}$ itself is rejected in religion according to the hadith, but most people who have not supported this idea failed in understanding the spirit and complexion of the nine saints purpose. Most people who are beliefs in the method of acculturation beliefs that this is the most suitable way to represent Islam in Indonesia, which are through something that suitable with the Indonesian root culture (Hinduism-Budha).

Besides the debate in the acculturation process, these artifacts are also facing some challenges which are. 1). Disconnection of value and spatial orientation between the past, the present, and the future. The sites usually become famous only in the main areas which are the mosque and the tomb as a pilgrimage area. For example, The Sunan Drajad site which is located in the East Java was the center of local economic development through a "batik Drajad" craft, but now only as pilgrimage area 2). The economic challenge, future orientation in managing the heritage based on economic preference (private sector) is more important than the value of the heritage itself either for government nor communities. 3). The management of the urban heritage is not based on the area activities but only on the main artifact, this is creating a disconnection between space, people and activities. 4). The management of the urban heritage is a low concern in an archeological and anthropology consideration that most urban planning document not using the heritage as main activities.

The problems in the heritage area caused by some main issues which are low understanding in Islamic urban heritage artifacts, sites and feature especially because of the acculturation. There is no integration of archeology, heritage, and urban planning. Therefore it is important to identify what are the category of artifacts and sites in urban heritage in Java and the acculturation that happened in the urban heritage sites and artifacts. The main purpose of this research is bridging the understanding and connecting value between past, presents, and future of Islamic heritage management in Indonesia.

\section{Theoretical Background}

\section{Archipelago Islamic Sites and Artifacts}

There are some elements of archeology that most people failed to understand that include the category of archeological findings categorization. Archeology elements are consist of artifacts, ecofacts, feature and sites (Oklahoma Public Archeology Network, 2017). An artifact is any portable object that was made or modified by humans and is at least 50 years old. Ecofacts, like artifacts, are portable findings. However, an ecofact is defined as a natural object, as bone and plant remain. Features are different from artifacts because unlike items such as spear points or potsherds, features cannot be transported or moved, the example is a mosque or house. Sites are an archaeological conglomeration of artifacts, ecofacts, and features. A site is the location of archaeological findings, and examples include cemeteries, villages, cliff dwellings (Oklahoma Public Archeology Network, 2017).The Islamic heritage archaeology as Tjandrasasmita (2009) mentioned scattered consist of many categories of findings which are consist of sites (usually in this sites is mosque, graveyard and also residential complex) and also a features (mosques, some building that have Islamic architectural and usually the supporting system of the mosque system, residential housing) and artifacts that consist of the art and writing manuscript, ornaments, coins, weapon, ceramics, stones and craving.

\footnotetext{
${ }^{1}$ Hadith: "He who innovates something that is not in agreement with our matter(religion), will have it rejected." [Al-Bukhari and Muslim]

${ }^{2}$ Hadith: One of the legal law source after the Qur'an. A narrative record of the sayings or customs of Muhammad and his companions or also the collective body of traditions relating to Muhammad and his companions.
} 
Whilst that can be denied that there is an ecofact category but none of the Tjandrasasmita, 2009 research has mentioned this. The structure of sites, features, and artifacts of Islamic urban heritage can be seen in the Table-1

Table -1. The Archipelago Islamic Archaeology Category

\begin{tabular}{|c|c|c|}
\hline Sites & Features & Artifacts \\
\hline $\begin{array}{l}\text { Sites of the mosque of the nine } \\
\text { saints (Walisongo); } \\
\text { Sites of the mosque of Islamic } \\
\text { kingdom; } \\
\text { - Residential complex; } \\
\text { - Sites of the Islamic kingdom } \\
\text { and administration place. }\end{array}$ & $\begin{array}{l}\text { - } \text { Mosque; } \\
\text { - } \text { Hraveyard; } \\
\text { - Giri (kind of administration } \\
\text { place of the Wali Songo or even } \\
\text { small kingdom). }\end{array}$ & $\begin{array}{l}\text { - } \text { Coins; } \\
\text { - Ceramics; } \\
\text { - } \text { Seapon; } \\
\text { Stone (including graveyard } \\
\text { - } \text { stone, gate, statue, etc); } \\
\text { - Ent and Written manuscript; } \\
\text { - } \\
\text { Etc. }\end{array}$ \\
\hline
\end{tabular}

Source: Interpretation from Tjandrasasmita, 2009 and Oklahoma Public Archeology Network, 2017

\section{Spatial Archaeology}

Spatial archaeology is a term defined by David L. Clarke (1977) to give meaning to a type of approach archeology that puts attention on dimensions space of archaeological objects and sites. It is basically a study of archeology which studies space found in past human activities, as well as learning relationship between spaces in one site to a site system along with the environment. Spatial archaeology focuses on the distribution of the archeology elements and spatial relations at the center of human activity, both deep micro scale (micro), meso (semi-micro), and macro (macro). This spatial archeology has been a foundation of many research to explain the importance of multidisciplinary studies in archeology and spatial (geography, planning and architecture domain). The idea of the spatial archaeology been developed into methods and also findings in archaeology developments.

The development of spatial archaeology been used in many findings that can be seen in Table -2. The main points to of the use of spatial archaeology are: 1).determinate the spatial integration between and also delineation between the sites, one of the significances finding including the clarification of the production falsely of the ancient Gallo-Roman cities city border. 2). Connecting value between past and presents with the expectations that the sustainability in the heritage area will accomplish. 3). To find the organization of the past space and also how to reflect it on the future development and last but not least is to 4). The development of methods for future development.

Table -2. The Importance of Spatial Archaology in Many Research Findings

\begin{tabular}{ll}
$\begin{array}{c}\text { The importance of spatial } \\
\text { archaeology research in } \\
\text { archeology }\end{array}$ & \multicolumn{1}{c}{ Findings of Investigation } \\
\hline $\begin{array}{l}\text { Spatial integration/ } \\
\text { Deliniation } \\
\text { (morphological approaches) }\end{array}$ & $\begin{array}{l}\text { Clarification of the production of falsely precise drawings of ancient Gallo-Roman cities } \\
\text { based on the reformulation of contemporary city borders. In spite of its limitations, this } \\
\text { approach provided a framework for an optimistic conception of the long-term } \\
\text { sustainability of ancient borders, widely applied in administrative and political } \\
\text { geography; }\end{array}$ \\
\hline $\begin{array}{l}\text { Connecting value past - presents } \\
\text { and future }\end{array}$ & $\begin{array}{l}\text { The importance of combining the geography study and archeology in order to create } \\
\text { chronical development from past to present to determine the future; }\end{array}$ \\
\hline Organization of Space & 1. $\begin{array}{l}\text { Spatial analysis has been a decisive factor for reflecting on the structure of the } \\
\text { settlement system, for example, The territory of Ugernum, a protohistoric oppidum } \\
\text { perpetuated as a Gallo-Roman agglomeration; } \\
\text { Giving statements to the construction of settlements network. One of the products is } \\
\text { "neighborhood legacy" concept }\end{array}$ \\
\hline
\end{tabular}




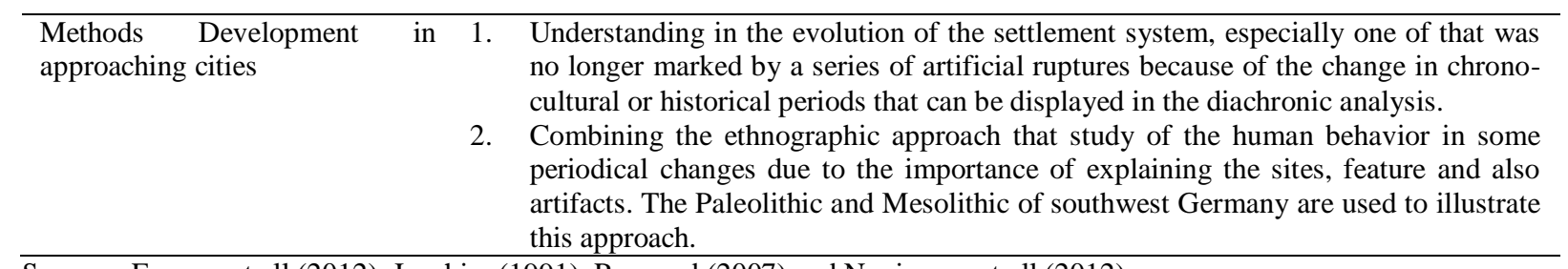

Sources: Favory, et all (2012), Joachim (1991), Raynaud (2007) and Nuninger , et all (2012).

\section{The Concept of The Space in Urban Islamic Heritage}

Lefebvre (1991) stated space as a means of production and become part of societies' base. Space is at once a precondition and a result of social superstructures. The idea in "The Production of Space" is that humans not only produce social relations and use-values but in doing so also produce social space. In more general terms, extending beyond social space to all physical spaces, one can say that each living body is space and has its space: it produces itself in space and it also produces that space. In society, humans produce social spaces. There is a dialectic of social relations and space: "Social relations, which are concrete abstractions, have no real existence save in and through space. Their underpinning is spatial". Lefebvre's concept of the boundary of social space is circumscribed by which a social space has physical borders and conceptual boundaries that are socially produced, but always interpenetrates and superimposes other spaces. How are boundaries communicated? Space can be marked physically or by discourse and signs so that it becomes a symbol. On the one hand, it can be nature that "communicates" the physical boundary of space to us. A habitable valley bounded by mountains into all directions has natural borders. The valley cannot easily be extended physically because the mountains border it. Only if something such as an earthquake or rock fall changes the mountain and the valley's geography can change such natural boundaries. Humans in society can intentionally produce signs to make objects symbolize and take on specific meanings that are culturally created, stored, disseminated, and communicated. The border of a nation state is physically marked by blockages of the national territory controlled by organs of the state, with the monopoly of violence. It is discursively marked by a distinction between citizens and non-citizens, communicated in the form of passports that grant access to, and provide certain rights within, a national territory

Yi Fu Tuan (1979) argues that space is not a single thing but may rather be approached as a multiplicity of mental constructions which all rely on the interaction between the human body and its environment. For his discussion of what space is and how to approach it, Tuan explores several themes to discuss space and methods to approach. In the approached theme of space and body, it is understood that original space possesses structure and orientation by the presence of the human body. Body implicates space; space coexists with the sentient body. This primitive relationship holds when the body is largely a system of anonymous functions before it can serve as an instrument of conscious choice and intention. Visual perception, touch, movement, and thought combine to give us our characteristic sense of space. The recognition of objects implies the recognition of intervals and distance relation among objects, and hence, of space. Another approach theme is space and the individual and space and the group. We are used to seeing the one map as a cartographic device summarize certain economic facts, and the other as a means for representing events in human geography. But the humanist geographer can read between the lines. The arrow represents his lived-space, which is also his lived-time. The first critic of space was followed by a critic of the notion of place in geography. Tuan argues that the notion does not strictly mean location, but goes beyond that. In the English language as in several others, place both carry a sense of location and social position which then defines the meaning of place by the following description. People demonstrate their sense of place when they apply their moral and aesthetic discernment to sites and locations. However, the world is known through the senses of hearing, smell, taste, and touch. These senses, unlike the visual, require close contact and long association with the environment. 
The concept of space in religion has been categorizing as a sacred and profane space. In the Hinduism than later adopted by Buddhism, the mandala concept has been used in the organization of space as quoted from Meister in Walcot, 2006 as follow:

"The cosmogrammatic mandala represents transitorily inhabited, constructed space. The earliest use of the term "mandala" referred to verses in the sacred Hindu Vedic scriptures (the "Atharva-Veda," early in the first millennium BC) that lirUced depictions of dwelling places of holy beings, cosmograms, and the human body. In the sixth century AD, the "Vastupurusamandlas" evoked a plan for cities and buildings similar to that of Wheatley's archetypal Pivot of Four Quarters, with ritual altars as a possible precedent, utilizing the construction device of apportioning space as in a metaphysical temple

In Hindu culture especially in Indonesia, every building or place must be facing the direction that has been determined and oriented to a central point of a city or place, this center is called Bindu or Windu. These directions are determined based on Hindu gods. In the Kingdom of Majapahit, the palace is located South of the Alun-Alun (city square), the central market is in the North of the Alun-Alun. While the Buddhist temple is in the West of the Alun-Alun, the Hindu temple located in the East of it. This space organization arrangement is also seen in the organization of space organizations in Kudus City, where the mosque is in West of the Alun-Alun as the recreated acculturation on the spatial form (Pradisa 2017; Walcott 2006)

This quite different than Islamic concepts of space that have no permanent sacred space except for Kaaba and Mecca as quoted in the previous research as follows "However, whilst Islam does, as we shall see, designate certain places as "sacred," it never loses sight of its fundamental conviction that all space is sacred place, and, through worship, architecture, and traditional city planning, tries to sacralize all space by extending the "sacred" into the "secular (Bennet in Holm, et al, 2001). The scared space in the Islamic view is something that can be produced and reproduce due to its terms and condition. Such as, make it clean from any dirt, use to perform the prayer while facing the qiblah direction and nobody can passing through in front of the sacred place while its use by some other for prayers. After the prayer is done than space is automatically transformed into mundane/ profane space. However, Tucunan (2011) describing the acculturation in Java has changed this characteristic of the sacred place. The sacred places in the sites of the wali sanga or nine saints are using the concept of sacred and profane as can be seen in figure. 1 .

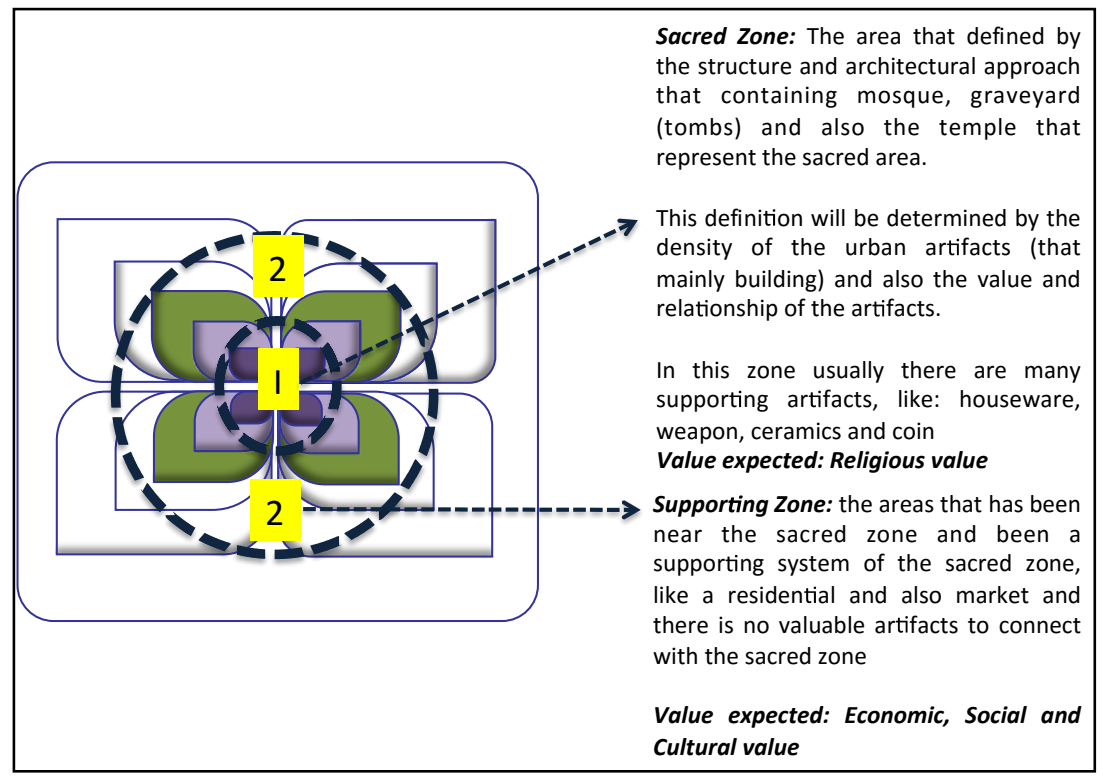


Figure. 1 Spatial Configuration in Indonesia Urban

Heritage Process Source: Tucunan, et all (2017)

\section{Methodology}

The research method using inductive and deductive approach. The inductive approach is using the ethnography in the sites of the nine saints site and while the deductive approach completes the information and analysis of the urban acculturation process. The unit analyzes are sites where the Islamic teaching spreading, which are the nine saints sites. The objects of analyzes are including the sites itself, the feature and also the artifact. This research has limitation findings of ecofacts in the sites of the nine saints. The site's description can be seen in Table. 3

Table -3. The Unit Analysis and Object of Analysis

\begin{tabular}{lll}
\hline \multicolumn{1}{c}{ Unit analysis } & Object of Analysis \\
\hline - & \multicolumn{1}{c}{ Heritage site and surrounding of Sunan Giri tomb; } & Sites; \\
thomb; & Feature; \\
- & Artifacts. \\
- Heritage site and surrounding Sunan Bonang tomb; & \\
- Heritage site and surrounding Sunan Drajad tomb; & \\
- Heritage site and surrounding Sunan Ampel tomb; & \\
- Heritage site and surrounding Sunan Muria tomb; & \\
\end{tabular}

\section{Results and Discussion}

\section{Acculturation in the sites spatial configuration}

The acculturation that happened in all sites consistent with Islam - Hindu acculturation concept. The morphological layout of the sites always consists of the sacred - profane zone. This concept supposed to be transformed as an adaptation to the Islamic rules, but in the sites, it appears to be consistent for the use of the sacred and profane zone that in Hindu concept exists as a permanent zone, although the activities are mixed between sacral and profane activities.

Sacred zones in the sites are usually mosque and tombs. To enter the area, there are a lot of gapura that showing sacred place (this is the results of acculturation with the Hinduism) some of the tombs located in the high land, clustered with the people that closed with the saints life, also some of the spatial configuration using mandala concept (mosque near the palace and central plaza). While in the profane zone can be found the housing complex of the local resident (kauman), usually some of them belong to certain ethnicity (Arabic or Chinese or Indian), the Arabic residence usually have a high density to show the closeness among them (representing ukhuwah Islamiyah conception) with the minimalist architecture that also happen in the old Arab resident,organic market in the surrounding of mosque (representation) in Islamic configuration. Some of the examples are The Sunan Muria sites that located in the highland to marked the secrecy of the sites and the use of gate like in transitional phase in Hindu religion in Sunan Muria and Sunan Ampel cases, as can be seen in Figure 2. 


\section{Case Study:}

Masjid Menara Kudus was established in the 15th-16th century during the early period of Islam spreading or da'wah in Java by Sunan Kudus, one of Wali Songo or the Nine Saints in Indonesia. This masjid is unique and historical because the process of acculturation of Hindu - Islam during the Sunan Kudus period was reflected in the masjid architecture. The da'wah value and method that reflected in Masjid Menara Kudus during the acculturation period of Sunan Kudus:

1. The tolerance of Islam. Blending with the existing culture that was Javanese Hindu culture;

2. The Islamic area in the spatial configuration later became the center of education area, mentioned as Kauman or Kampung Kauman;

3. Mandala concept in ancient Javanese spatial form that was acculturated from Hindu and Buddha, while the acculturation of Islam shown that Masjid has changed the position of Pura in Mandala concept, that is in the Westside according to the ancient Javanese Mandala configuration.

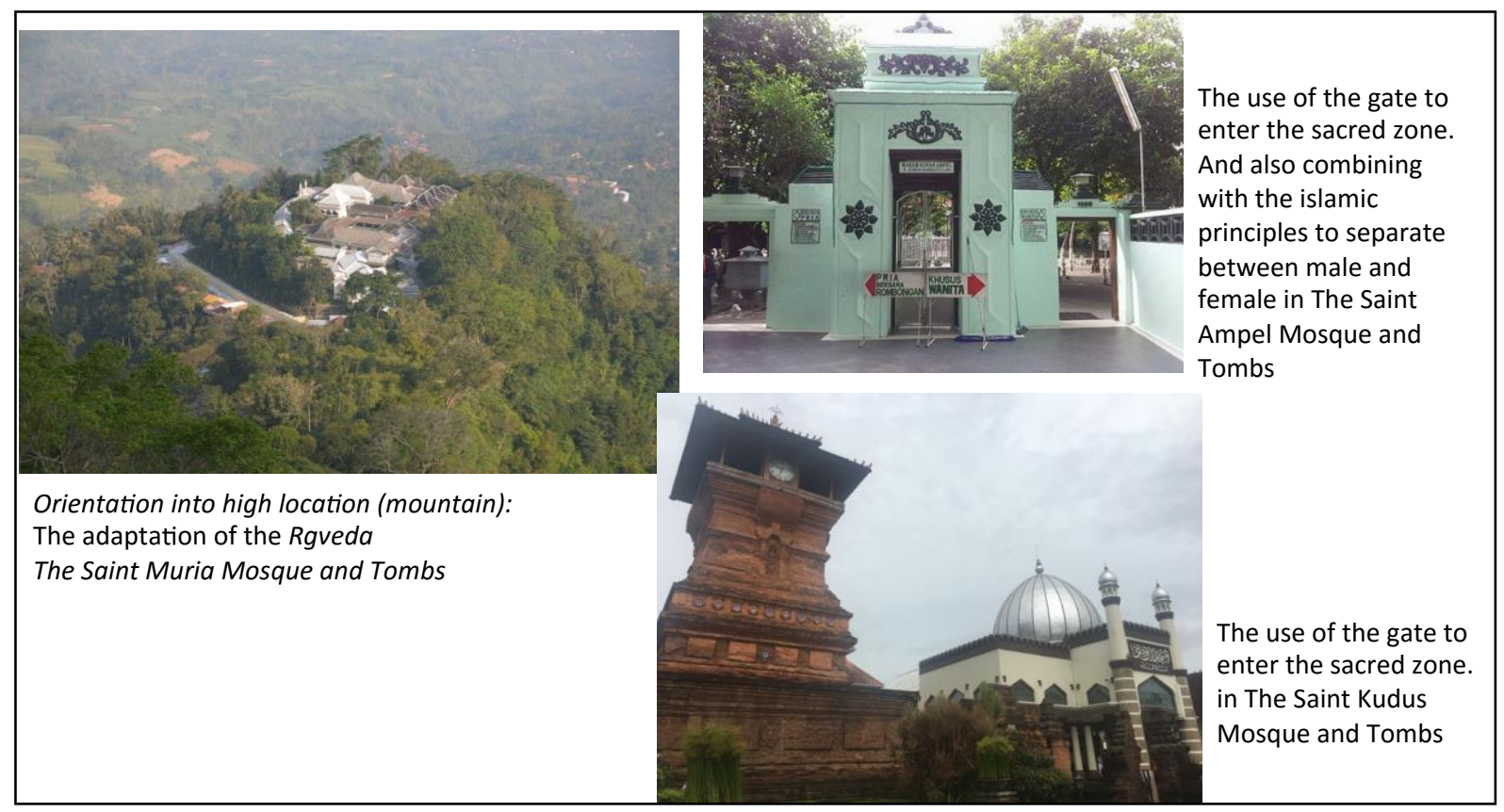

Fig. 2 Sunan Muria, Sunan Ampel and Sunan Muria Islamic Heritage Sites 


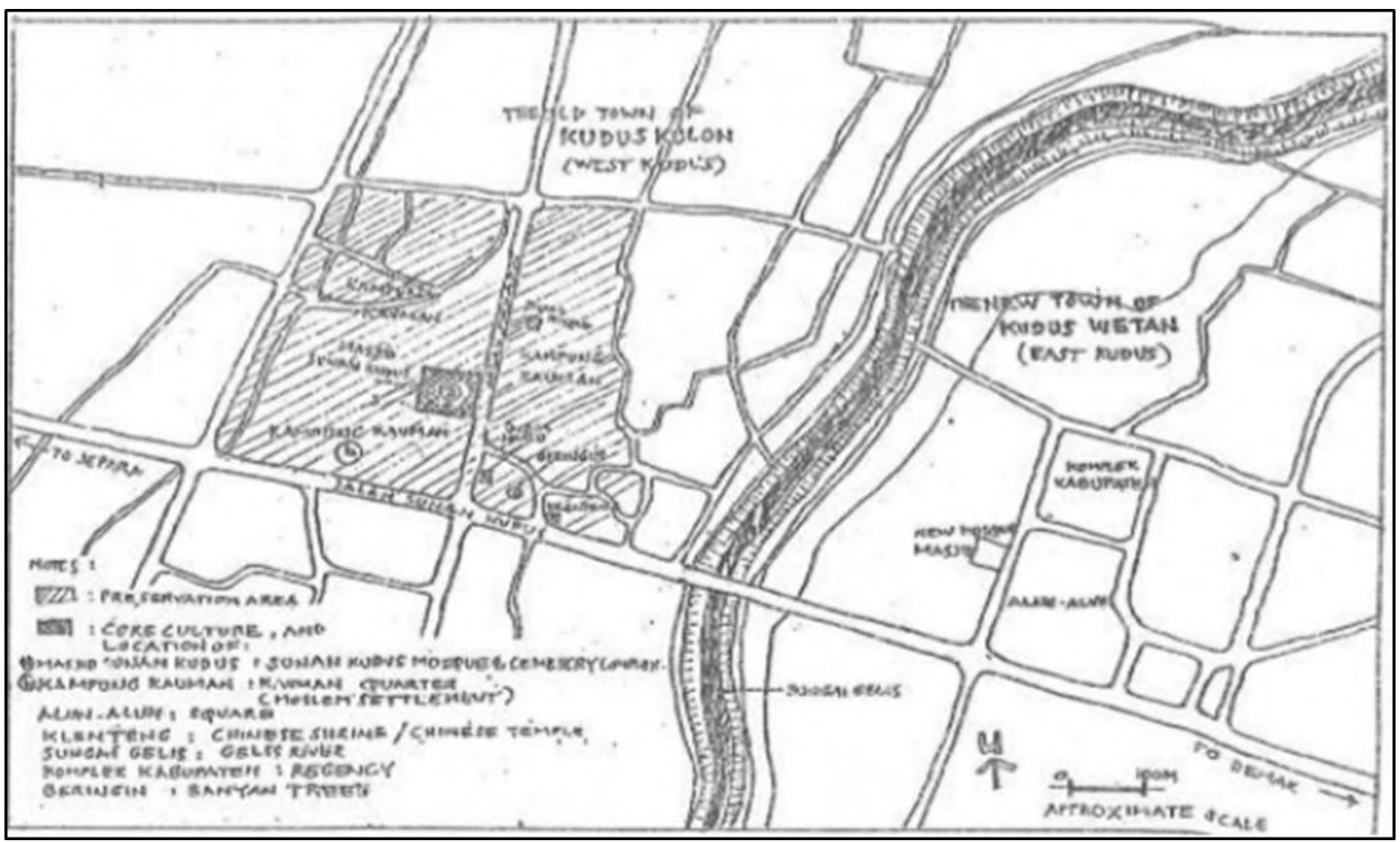

Fig. 3 Masjid Menara Kudus and Kampung Kauman spatial configuration in Kudus Source:Pradisa, 2017

In Figure 3 can be seen that Alun-Alun as a plaza or central public space also the landmark of the city/town, Masjid as the da'wah center and sacred area, Kauman as the housing area and education center. The western part of Kudus (Kudus Kulon) is intended for the town square, trade, and government/ administration. Whereas the East section of Kudus (Kudus Wetan) consists of community settlements and traditional cigarette factories. The Western and Eastern part of the City of Kudus is connected by a bridge. Masjid Menara Kudus and Sunan Kudus' tomb located in Kudus Kulon, precisely in Kampung Kauman. Since the colonial period, this area had been functioned as an education center. The Alun-Alun was located in the Eastern part of the Masjid. The layout of the Masjid Menara Kudus can be seen in Figure 4.

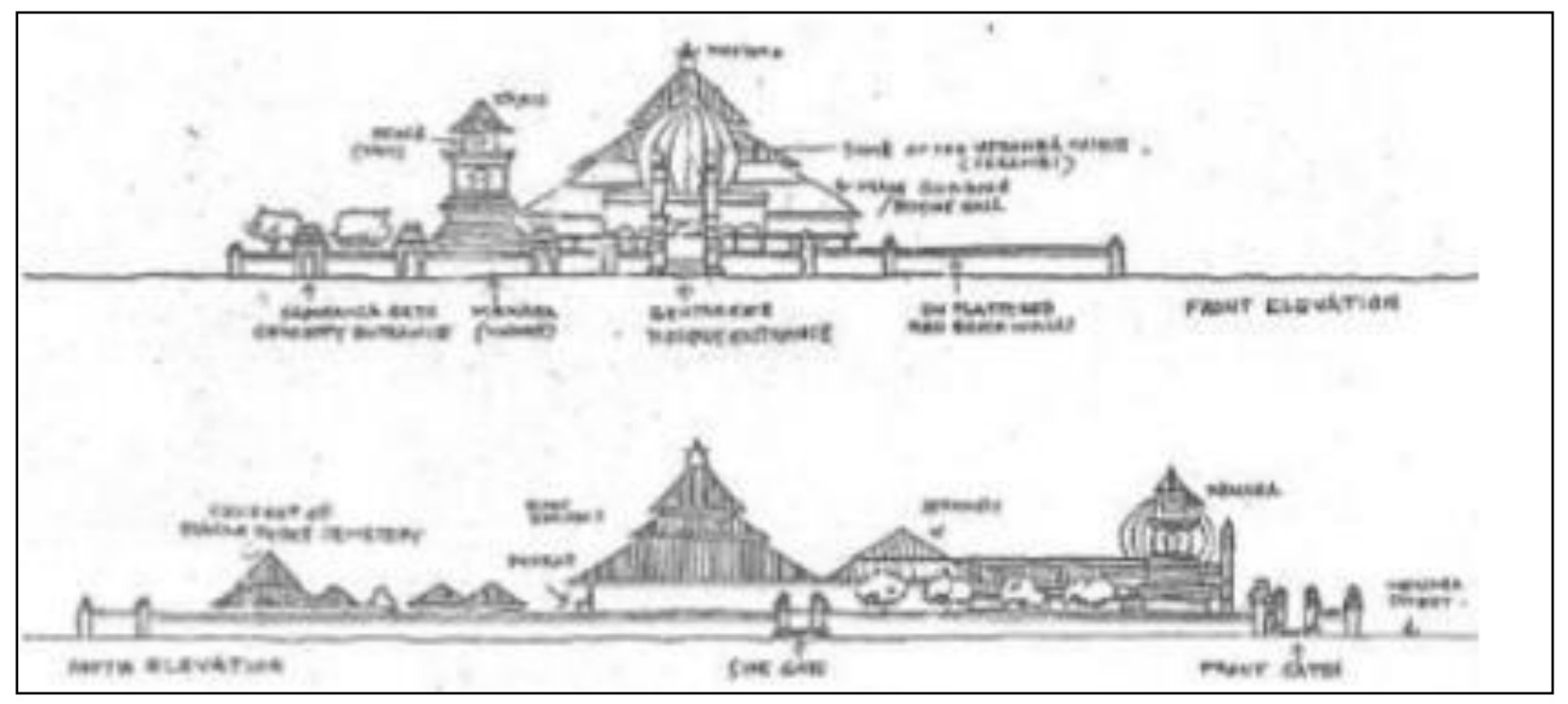

Fig. 3 Layout (right) and façade (upper) of Masjid Menara Kudus.Source:Pradisa, 2017

Masjid Menara Kudus has an area of approximately 5,000 m2 with walls bordering around the masjid with surrounding settlements. To enter the Masjid Menara Kudus you can go through two gates 
called Gapura Bentar. This gate is located both in the North and South side of the masjid (Figure 5a and $5 \mathrm{~b}$ ). The North gate is the main access to directly enter the mosque from the Alun-alun side. While the South gate is the gate that leads to the cemetery. The name Gapura Bentar is taken from the Hindu term which means the gate. In entering the Masjid Menara Kudus there is no special procession, quite different from the prior function as temple buildings that have special rules for entering buildings. But naming the two main gates in the Masjid Menara Kudus shows that the influence of Hindu culture is still influencing in the construction period of the masjid.

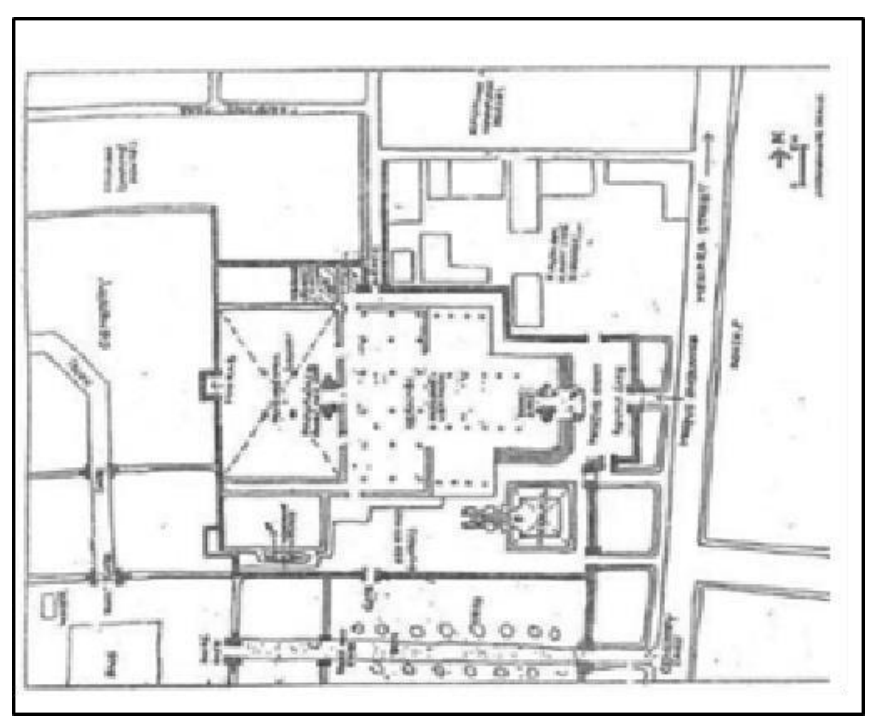

Fig. 5a Gapura Bentar as front and back entrance of Masjid. Source:Pradisa, 2017

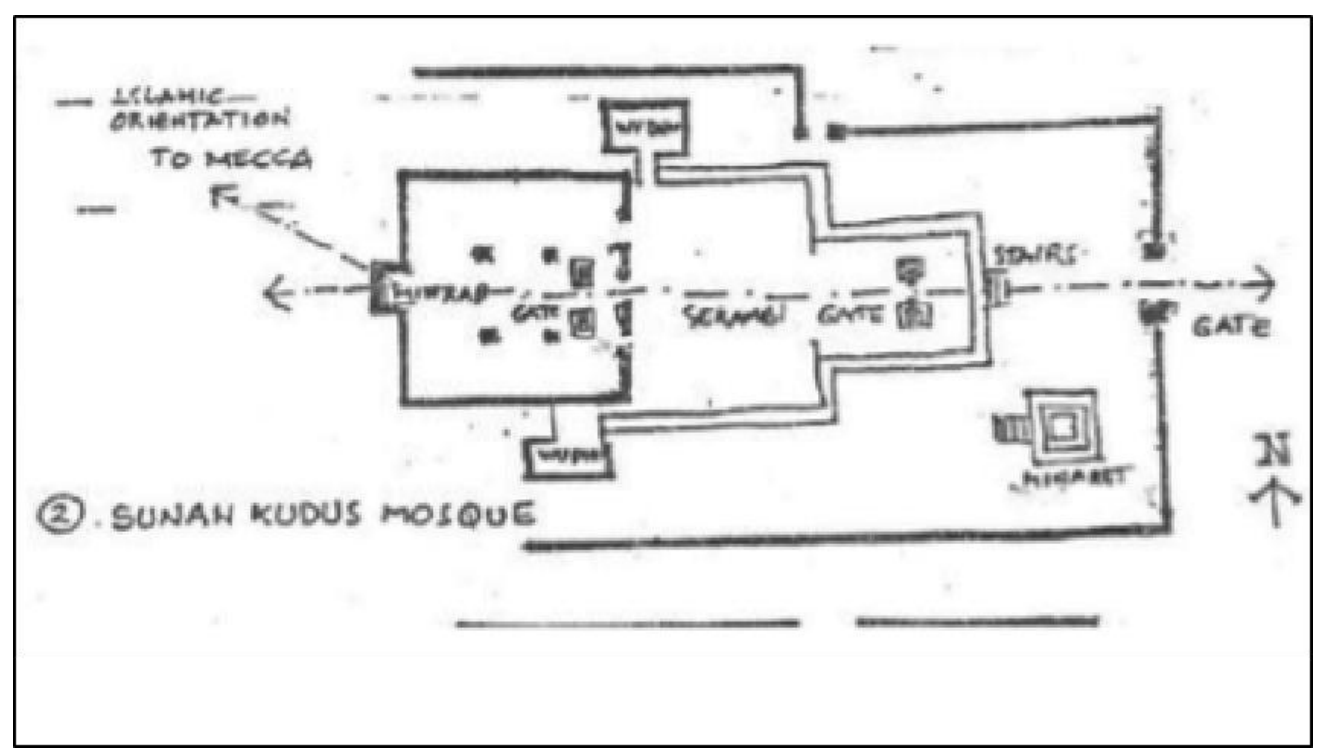

Fig. 5b Gapura Bentar as front and back entrance of Masjid. Source:Pradisa, 2017 


\section{Acculturation in architectural design and ornaments (features and artifacts):}

The acculturation in architectural design and ornaments (artifacts) can be found in the features and artifacts as follow:

- The mosque design: some of the mosques still has paduraksa or gapura which is Indonesia adaptation of Gopuram, like in Lawang Sewu and some tombs.

- The use of adapted "Pallawa" in the engraving of tombs;

- Using of the cungkup that represented temple in the Hinduism;

- Use of the Arabic letters and symbol in the graveyard;

- Use of the ceramics that indicating the acculturation with a Chinese. The illustration of the features and artifacts can be seen in Figure 6.

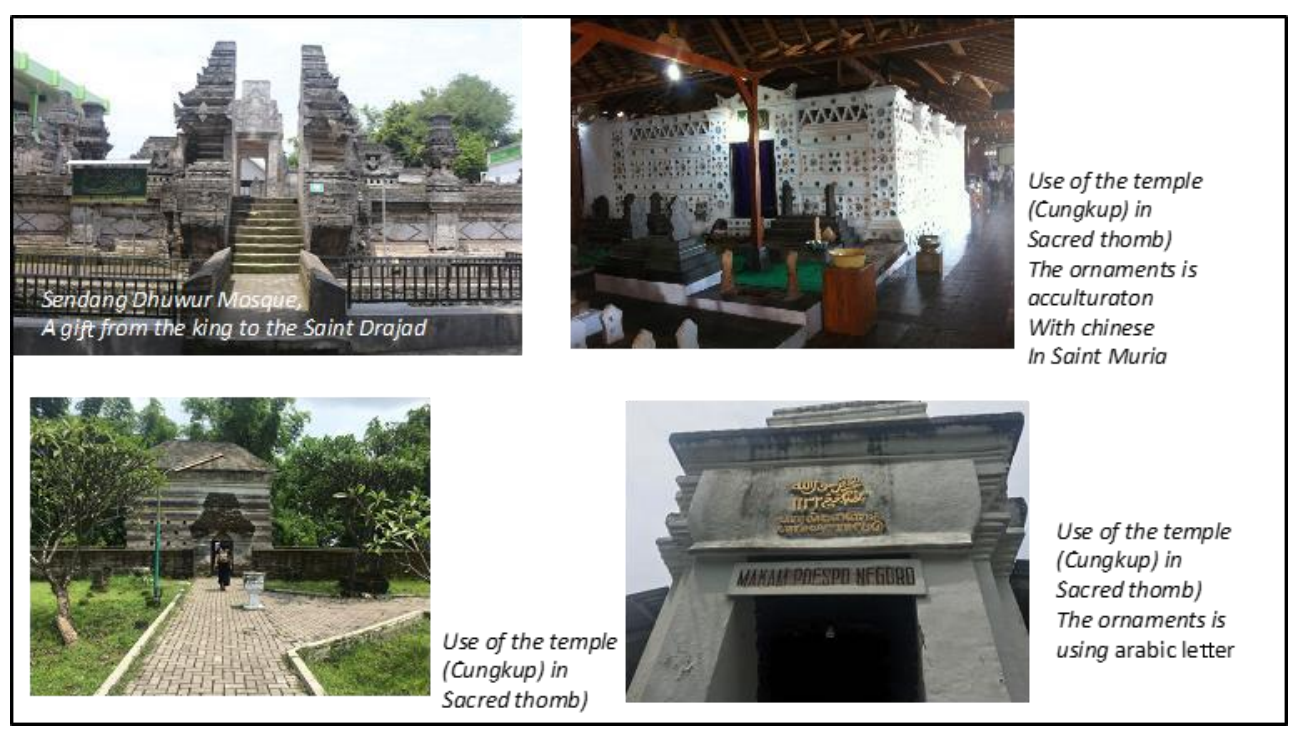

Fig. 6 The Illustration of Form Acculturation in Features and Artifacts

\section{Case Study}

Acculturation in layout configuration Kaaba in Makkah as orientation in praying has been the main standard in building the Masjid also the main gate and masjid position in a bigger spatial configuration adapted from ancient Mandala concept shown in Figure 5b. Organic anatomy of Menara (Tower) that adapted Javanese Hindu: Head, Body, and Foot typology is shown in Figure 7. 


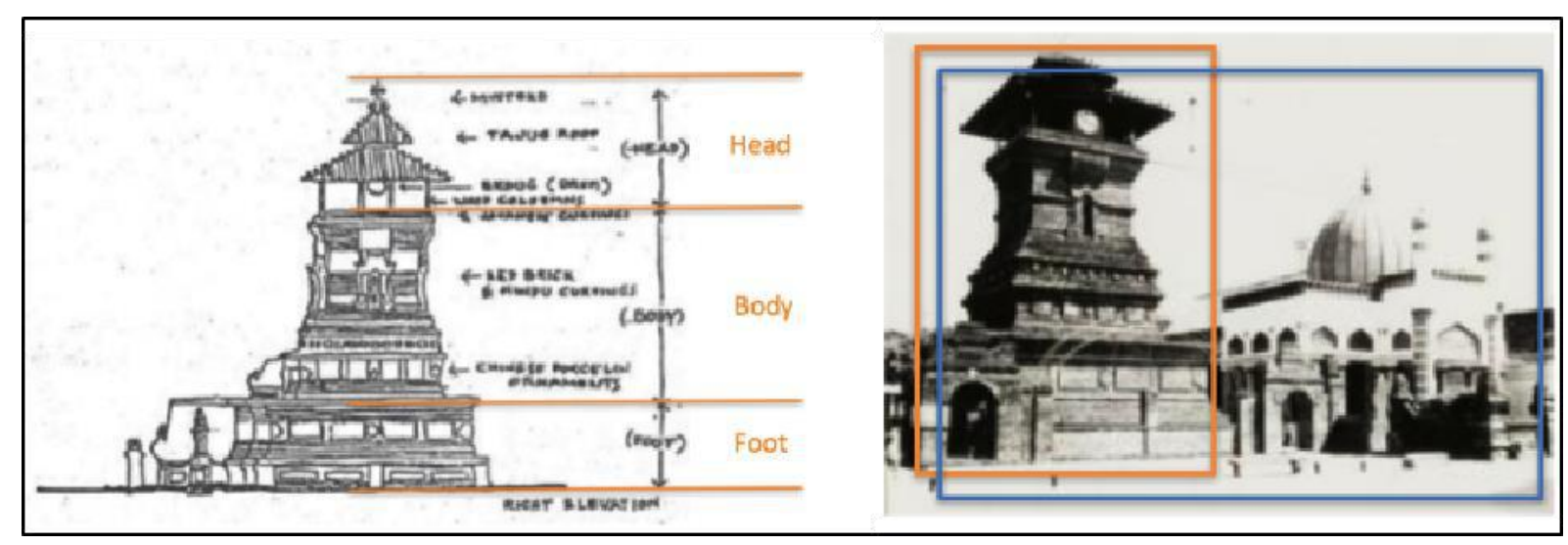

Fig. 7 Menara or Tower as symbol of Acculturation Source: Pradisa, 2017

Menara as a symbol of acculturation with the existing local culture, built as a part of Masjid Menara Kudus. Menara or Tower as visual dominant of the Masjid with Hindu sculpture in the below part whereas roof, space below the roof (relung) and four columns supporting relung was also adopted from the ancient Javanese Hindu shown in Figure 6. The tower section in the Menara Kudus Mosque is visually dominant. Menara Kudus was built with red brick material with an area of $100 \mathrm{~m} 2$ and a height of $18 \mathrm{~m}$. At the bottom of the tower are carvings with Hindu motifs. The roof of the tower consists of a two-level tajug roof with four columns supporting it. This shows the Hindu elements that were applied in the construction of the tower. Apart from building materials that are different from the mosque building, the proportions and shapes of the Menara Kudus also show the Hindu elements that dominate the Masjid Menara Kudus complex.

Acculturation in the art and writing artifacts

The acculturation in architectural art and writing artifacts can be seen as follow:

- $\quad$ Art and writing artifacts: nine saints write a lot about Islamic manuscript in the storytelling that uses Arabic letter but the language remains in Javanese, like layang anbiya manuscript: Manuscript in song and poetry in the Javanese using Islamic principle, like Tombo ati (remedies of the heart). This song created originally without music and in the Javanese language. This is one of the acculturation that happened in Indonesia because the text turns out taken from Arabic book by Ibn Jauzi $(527 \mathrm{H})$ when written about shifat ash shafwah Yahya Bin Muadz Ar Razi as written on the table-4 and then it copied again in Imam Nawawi Kuttab Al Adzkar.

Table -4. The Javanese and Meaning in English Songs The Remedies of The Heart

\begin{tabular}{l|l}
\hline Javanese Teks & Meaning (in English) \\
\hline Tombo Ati iku limo perkorone & There are five remedies of heart \\
Kaping pisan moco Kuran lan maknane & First, read the Quran and understand its meaning \\
Kaping pindo sholat wengi lakonono & Second, do the night prayer \\
Kaping telu wong kang soleh kumpulono & Third, gather with pious people \\
Kaping papat wetengiro ingkang luwe & Fourth, fast (literally: keep a hungry stomach) regularly \\
Kaping limo zikir wengi ingkang suwe & Fifth, do long zikir at night \\
Salah sawijine sopo iso ngelakoni & Anyone who can do even one of thosemay he Lord God \\
Mugi-mugi Gusti Allah nyembadani & (Allah) bless \\
\hline
\end{tabular}


-Art and writing artifacts: People in Indonesia was familiar with Ramayana and Mahabarata performance that perform using the puppet. The puppet is used by the nine saints to tell the story about Islam and gradually change the perform to follow the Islamic rules, like: no god is allowed to be shown in the performance, the shape of the puppet not allowed to be exactly resemble human, the using of the shadow to perform, now the artifacts call wayang kulit, some of the illustrations can be seen in figure 5 .

-The use of the mixed ornaments in daily life, like ceramics as a houseware from China and use for the ornaments in the mosque and tombs, some of the illustrations can be in figure 8 .

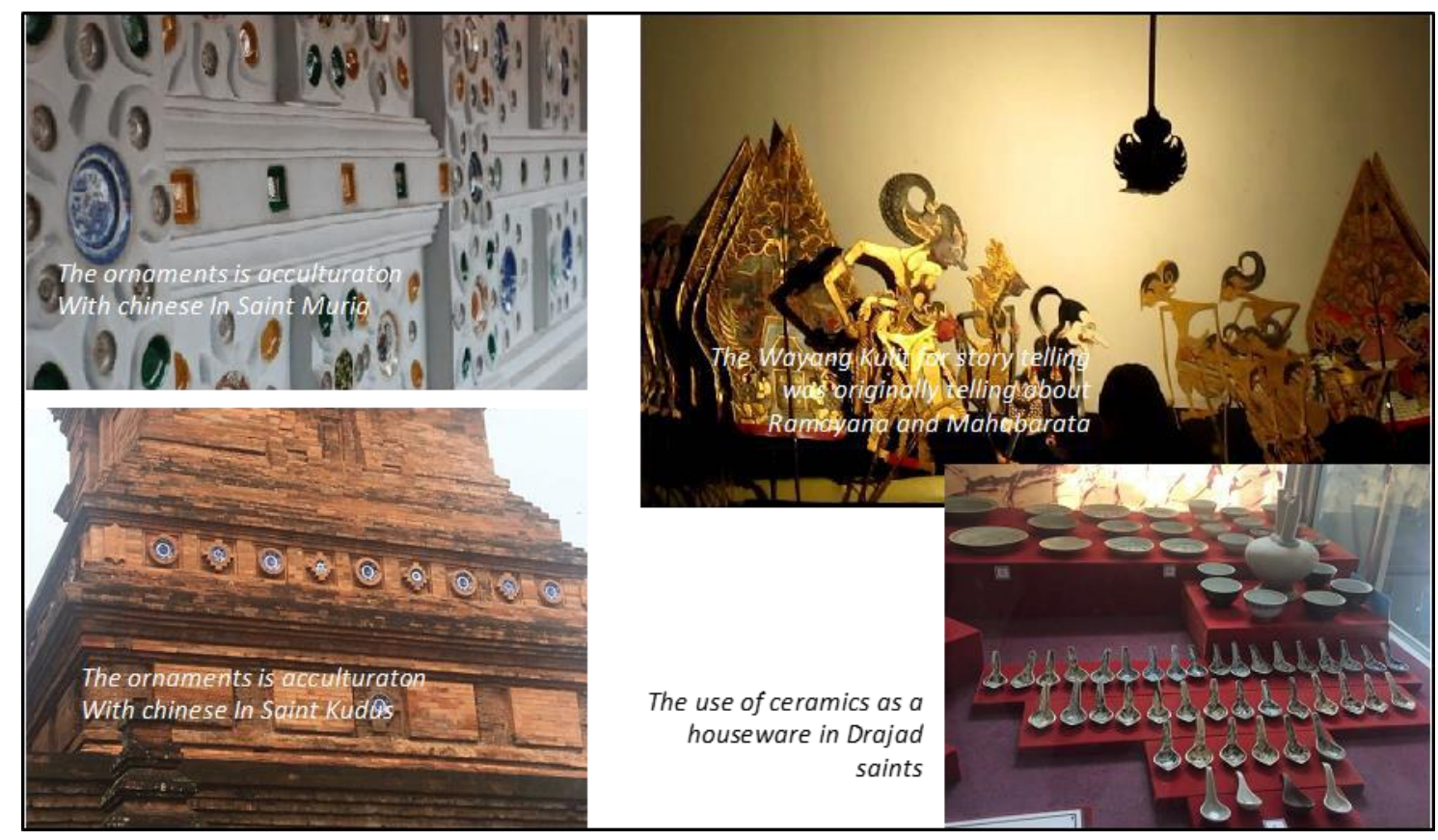

Fig. 8 Acculturation of Urban Artifacts

\section{Conclusion}

The main conclusion of this research is findings that Indonesian people were adept to outside culture, even embraced it as their own. Many manuscripts, sites, features and also artifacts of the Indonesia heritage is acculturated from at least two culture which are consists of the interpretation of Indonesia people and also the outside culture. That is way, This is the living evidence of the truest Indonesian identity that most Indonesian forgot. Of course, there is need further research in more detailed aspects of the acculturation and the impact of the development as the identities of the city/ region in Indonesia.

\section{References}

[article in a journal]

Favory, F., Nuninger, L. \& Sanders, L. (2012). Intégration de concepts de géographie et d'archéologie spatiale pour l'étude des systèmes de peuplement. L'Espace géographique, vol. 41,(4), 295-309. https://www.cairn.info/revue-espace-geographique-2012-4-page-295.htm. 
Susan M. Walcott (2006) Mapping from a Different Direction: Mandala as Sacred Spatial Visualization, Journal of Cultural Geography, 23:2, 71-88, DOI: 10.1080/08873630609478223

Tucunan, K. P., Sulistyandari, U., \& Perkasa, M. I. (2018). Artefak Dalam Konteks Perkembangan Kawasan Heritage Islam. Jurnal Planologi, 15(2), 134-148. Universitas Diponegoro. DOI:

[Book]

Azra, Azumardi (2013). Jaringan Ulama' Timur Tengah dan Kepulauan Nusantara Abad XVII \& XVII. Jakarta, Penerbit Kencana.

Holm, J., \& Bowker, J. (2001). Sacred Place. Bloomsbury Publishing.

Jochim, M. A. (1991). Archeology as Long-Term Ethnography. American Anthropologist, 93(2).

Kennedy, R., \& Widjojoatmodjo, A. K. (1943). Acculturation and administration in Indonesia. American Anthropologist, 45(2), 185-192

Lefebvre, Henry. (1991). The Production of Space. Malden, MA: Blackwell. Original work published in 1974.

Pradisa, Andanti Puspita Sari. (2017). Perpaduan Budaya Islam dan Hindu dalam Masjid Menara Kudus. SAPPK ITB.

Raynaud C. (2007). Archéologie d'un village languedocien. Lunel-Viel (Hérault) du Ier au XVIIIe siècle. Lattes: Publications de l'Umr 5140 du Cnrs, Édition de l'Association pour le développement de l'archéologie en Languedoc-Roussillon, coll. "Monographies d'archéologie méditerranéenne", 407 p.

Tjandrasasmita, U. (2009). Arkeologi Islam Nusantara. Kepustakaan Populer Gramedia bekerja sama dengan École française d'Extrême-Orient dan Fakultas Adab dan Humaniora UIN Syarif Hidayatullah.

Tuan, Yi Fu. (1979). Space and Place: The Perspective of Experience. The University of Minnesota.

[Report, proceedings, and unpublished literature (a)]

Nuninger L., Verhagen P., Tourneux F.-P., Bertoncello F., Jeneson K. (2012). "Contextes spatiaux et transformation du système de peuplement : approche comparative et prédictive".In Bertoncello F., Berger J.F., Carozza L., Braemer F., Depaepe P., Variabililité environnementale, mutations sociales, nature, intensités, échelles et temporalités des changements, XXXIIe Rencontres internationales d'archéologie et d'histoire d'Antibes. Sophia-Antipolis: APDCA, p. 139-154.

[Internet source (with title, date of access and the universal resource locator in full)] UNO,

The Oklahoma Public Archaeology (2017), Date of access:14/04/2019.

https://okpublicarchaeology.wordpress.com/2017/08/23/artifacts-ecofacts-features-and-sites-a-lesson-inarchaeological-jargon/ 